\title{
BALANCING GUAVA NUTRITION WITH LIMING AND FERTILIZATION ${ }^{1}$
}

\author{
AMANDA HERNANDES ${ }^{2}$, SERGE-ÉTIENNE PARENT ${ }^{3}$, \\ WILLIAM NATALE ${ }^{4}$, LÉON ÉTIENNE PARENT ${ }^{3}$
}

ABSTRACT - Guava response to liming and fertilization can be monitored by tissue testing. Tissue nutrient signature is often diagnosed against nutrient concentration standards. However, this approach has been criticized for not considering nutrient interactions and to generate numerical biases as a result of data redundancy, scale dependency and non-normal distribution. Techniques of compositional data analysis can control those biases by balancing groups of nutrients, such as those involved in liming and fertilization. The sequentially arranged and orthonormal isometric log ratios (ilr) or balances avoid numerical bias inherent to compositional data. The objectives were to relate tissue nutrient balances with the production of "Paluma" guava orchards differentially limed and fertilized, and to adjust the current patterns of nutrient balance with the range of more productive guava trees. It was conducted one experiment of 7-yr of liming and three experiments of 3-yr with N, P and K trials in 'Paluma' orchards on an Oxisol. Plant N, P, K, Ca and Mg were monitored yearly. It was selected the $[\mathrm{N}, \mathrm{P}, \mathrm{K} \mid \mathrm{Ca}, \mathrm{Mg}],[\mathrm{N}, \mathrm{P} \mid \mathrm{K}],[\mathrm{N} \mid \mathrm{P}]$ and $[\mathrm{Ca} \mid \mathrm{Mg}]$ balances to set apart the effects of liming $(\mathrm{Ca}-\mathrm{Mg})$ and fertilizers $(\mathrm{N}-\mathrm{K})$ on macronutrient balances. Liming largely influenced nutrient balances of guava in the Oxisol while fertilization was less influential. The large range of guava yields and nutrient balances allowed defining balance ranges and comparing them with the critical ranges of nutrient concentration values currently used in Brazil and combined into ilr coordinates.

Index terms: Psidium guajava, compositional data analysis, isometric log ratios (ilr), plant mineral nutrition, Aitchison geometry.

\section{EQUILÍBRIO NUTRICIONAL DE GOIABEIRAS A PARTIR DA CALAGEM E ADUBAÇÃO}

RESUMO - A resposta da goiabeira à calagem e à adubação pode ser monitorada por análises de tecido vegetal. O perfil nutricional é definido em relação a padrões de teores de nutrientes. No entanto, os teores de nutrientes-padrão são constantemente criticados por não considerarem as interações que ocorrem entre nutrientes e por gerarem tendências numéricas, decorrentes da redundância dos dados, da dependência de escala e da distribuição não normal. As técnicas de análise composicional de dados podem controlar esses dados tendenciosos, equilibrando os grupos de nutrientes, tais como os envolvidos na calagem e na adubação. A utilização das relações log isométricas (ilr) ortonormais, sequencialmente dispostas, evita tendências numéricas inerentes aos dados de composição. Os objetivos do trabalho foram relacionar o balanço de nutrientes dos tecidos vegetais com a produção de goiabeiras em pomares de 'Paluma' diferentemente corrigidos e adubados, e ajustar os atuais padrões de nutrientes com a faixa de equilíbrio das goiabeiras mais produtivas. Um experimento de calagem de sete anos e três, experimentos de três anos com doses de $\mathrm{N}, \mathrm{P}_{2} \mathrm{O}_{5}$ e $\mathrm{K}_{2} \mathrm{O}$, foram conduzidos em pomares de goiabeiras 'Paluma' em um Latossolo Vermelho-Amarelo. Os teores de N, P, K, Ca e Mg na planta foram monitorados anualmente. Selecionaram-se os balanços [N, $\mathrm{P}, \mathrm{K} \mid \mathrm{Ca}, \mathrm{Mg}],[\mathrm{N}, \mathrm{P} \mid \mathrm{K}],[\mathrm{N} \mid \mathrm{P}]$ e $[\mathrm{Ca} \mid \mathrm{Mg}]$ para separar os efeitos da calagem (Ca-Mg) e dos fertilizantes $(\mathrm{N}-\mathrm{K})$ nos balanços de macronutrientes. Os balanços foram mais influenciados pela calagem do que pela fertilização. A produtividade das goiabeiras e seu balanço nutricional permitiram a definição de faixas de equilíbrio de nutrientes e sua validação com as faixas de concentrações críticas atualmente utilizadas no Brasil e combinadas em coordenadas ilr.

Termos de Indexação: Psidium guajava, análise composicional de dados, relações log isométricas (ilr), nutrição mineral vegetal, geometria de Aitchison.

\footnotetext{
${ }^{1}$ (Trabalho 138-12). Recebido em:10-04-2012. Aceito para publicação em:18-10-2012. Part of the Ph.D. thesis by the senior author. ${ }^{2}$ Pós-Graduanda, Departamento de Solos e Adubos, Unesp, Universidade Estadual Paulista. Bolsa Sanduiche CAPES, junto a Université Laval, Québec, Canada. E-mail: amahernandes@hotmail.com

${ }^{3}$ ERSAM, Department of Soils and Agrifood Engineering, Université Laval, Québec (Qc), Canada G1V 0A6. E-mail: serge-etienne. parent1@ulaval.ca; leon-etienne.parent@fsaa.ulaval.ca

${ }^{4}$ Professor Adjunto, Departamento de Solos e Adubos, Unesp, Universidade Estadual Paulista, 14870-000, Jaboticabal, São Paulo, Brasil. E-mail: natale@fcav.unesp.br
} 


\section{INTRODUCTION}

Brazil is the world's largest producer of red guava (Psidium guajava L.), a fruit native to South and Central America. Guava is consumed fresh or transformed into jelly and juice. Fruits of the cultivar Paluma are oval, tasty, with an average weight of 140-250 grams, yellow skin, and red pulp, firm, resistant to transportation and storage, and suitable for both transformation and the fresh market.

Guava is responsive to liming (PRADO; NATALE, 2004, 2008; NATALE et al., 2005; NATALE et al., 2007) and fertilization (NATALE et al., 1996; NATALE et al., 2002a; ANJANEYULU; RAGHUPATHI, 2009). To achieve nutrient balance, liming and fertilization should be balanced accordingly. Guava response to liming and fertilization can be monitored by tissue testing. Tissue analysis has advantage over surface soil analysis as diagnostic tool for a deep rooted fruit crops because the plant have access to nutrient deeper in the soil than would be found through normal soil analytical procedures and is gaining in popularity (NATALE et al., 2002a).

The interpretation of plant tissue analyses is based on the contention that changes in nutrient supply are reflected in the nutrient composition of the diagnostic tissue and are more pronounced at certain stages of the plant development than at others (BOULD, 1968). However, nutrient concentration standards were criticized for not accounting for nutrient interactions (BATES, 1971) since several dual and multiple interactions have been well documented in plants (MALAVOLTA, 2006). The Diagnosis and Recommendation Integrated System (DRIS) using dual ratios or products may account in part for nutrient interactions (WALWORTH; SUMNER, 1988) but is geometrically deficient (PARENT, 2011). Parent and Dafir (1992) adjusted the DRIS procedure to fit into the centred log ratio transformation used to analyze compositional data such tissue concentration data (AITCHISON, 1986).

Plant tissue data convey relative information and are intrinsically multivariate since each component cannot be interpreted without relating it to any of the other components (TOLONASA-DELGADO; BOOGART, 2011). Lagatu and Maume (1935) were the first to illustrate the effect of changing the proportions of interacting nutrients in a closed system by a ternary diagram representing a three-component mixture system constrained to $100 \%$. A $D$-part compositional vector contains one redundant part as computed by difference between some whole and the other parts; as a result, there is at least one negative correlation (AITCHISON, 1986) and $D-1$ non redundant variables (EGOZCUE; PAWLOWSKYGLAHN, 2005). In addition, there are three dual ratios in a $D$-part compositional, but one is redundant as computed from the two others, i.e. $\mathrm{K} / \mathrm{Ca}=[(\mathrm{K} /$ $\mathrm{Mg}) /(\mathrm{Ca} / \mathrm{Mg})]$.

To avoid numerical bias inherent to compositional data and generate $D$-1 variables, Egozcue and Pawlowski-Glahn (2005) proposed using sequentially arranged and orthonormal isometric log ratios (ilr) based on the principle of orthogonality. The ilr coordinates can be projected into the Euclidean space, a geometrical framework that allows computing statistics without numerical bias. The ilr method is conducted in three steps: representation of data in ilr coordinates, variance analysis of the coordinates as real random variables, and interpretation of the results in terms of balances (EGOZCUE; PAWLOWSKY-GLAHN, 2011). The ilr concept was tested successfully in plant nutrition (PARENT, 2011), as well as studies in soil aggregation (PARENT et al., 2012).

The objective was to compare the effects of liming and N-P-K fertilization on tissue macronutrient (N, $\mathrm{P}, \mathrm{K}, \mathrm{Ca}, \mathrm{Mg}$ ) balances of 'Paluma' guava using the unbiased ilr approach and nutrient standards currently used in Brazil.

\section{MATERIAL AND METHODS}

\section{Lime experiment}

A liming experiment was conducted by Natale et al. (2007) and Prado and Natale (2008) with 'Paluma' during seven years (19992006) at Bebedouro (São Paulo) on a moderate, medium texture, alic, typical dystrophic, Haplustox (EMBRAPA, 2006). There were 5 liming rates replicated 4 times and arranged in a randomized block design. The limestone was incorporated into the soil in August 1999 and the one-year old 'Paluma' seedlings propagated from cuttings were planted in December 1999. The treatments consisted of increasing rates of limestone up to expected base saturation (EBS) of $70 \%$ considered adequate for guava (SANTOS; QUAGGIO, 1996). Lime rates were calculated for the $0-30 \mathrm{~cm}$ layer as follows: $\mathrm{D}_{0}$ $=$ zero limestone; $\mathrm{D}_{1}=$ half the dose to reach $\mathrm{EBS}$ of $70 \%, \mathrm{D}_{2}=$ dose to reach EBS of $70 \%, \mathrm{D}_{3}=1.5$ times the dose to reach EBS of $70 \%$ and $\mathrm{D}_{4}=2$ times the dose to reach EBS of $70 \%$, corresponding to $0.0,1.9$, 3.8, 5.6 and 7.4 ton $\mathrm{ha}^{-1}$ of limestone, respectively. The limestone contained $455.5 \mathrm{~g} \mathrm{~kg}^{-1}$ of $\mathrm{CaO}$ and $102.1 \mathrm{~g} \mathrm{~kg}^{-1}$ of $\mathrm{MgO}(\mathrm{Ca} / \mathrm{Mg}$ molar ratio of 3.2). Relative efficiency (grain size distribution of liming materials) was $93.72 \%$ and neutralizing power was 
$106.85 \%$. Lime was manually applied uniformly over the entire area, one half before incorporation with a moldboard plow and the other half followed by incorporation with a disc harrow.

Each $7 \mathrm{~m}$ by $4.2 \mathrm{~m}$ plot comprised five plants of which three were monitored. Fertilizer additions tree ${ }^{-1}$ were $140 \mathrm{~g} \mathrm{~N}$ and $112 \mathrm{~g} \mathrm{~K}_{2} \mathrm{O}$ in the $1^{\text {st }}$ year; 200 $\mathrm{g} \mathrm{N}$ and $50 \mathrm{~g} \mathrm{~K}_{2} \mathrm{O}$ in the $2^{\text {nd }}$ year; $200 \mathrm{~g} \mathrm{~N}, 30 \mathrm{~g} \mathrm{P}_{2} \mathrm{O}_{5}$ and $150 \mathrm{~g} \mathrm{~K}_{2} \mathrm{O}$ in the $3^{\text {rd }}$ year; $400 \mathrm{~g} \mathrm{~N}, 60 \mathrm{~g} \mathrm{P}_{2} \mathrm{O}_{5}$ and $300 \mathrm{~g} \mathrm{~K}_{2} \mathrm{O}$ in the $4^{\text {th }}$ year; $800 \mathrm{~g} \mathrm{~N}, 50 \mathrm{~g} \mathrm{P}_{2} \mathrm{O}_{5}$ and 300 $\mathrm{g} \mathrm{K}_{2} \mathrm{O}$ in the $5^{\text {th }}$ year; $800 \mathrm{~g} \mathrm{~N}, 50 \mathrm{~g} \mathrm{P}_{2} \mathrm{O}_{5}$ and $300 \mathrm{~g}$ $\mathrm{K}_{2} \mathrm{O}$ in the $6^{\text {th }}$ year. Fertilizers were applied at 3 to 4 occasions during the growing season. In the $2^{\text {nd }}, 3^{\text {rd }}$ and $4^{\text {th }}$ years, bovine compost (no chemical analysis provided) was added at a rate of $40 \mathrm{~L} \mathrm{tree}^{-1}$. Fertilizer sources were urea and ammonium sulfate $(1: 1)$, either triple superphosphate or mono-ammonium phosphate, and potassium chloride. The fertilizers were broadcast around the plant in a band $40 \mathrm{~cm}$ wide beyond crown projection. Each year from 2002 to 2006 , yield, number and weight of fruits were determined weekly and, occasionally, 2-3 times per week during the harvest period that extended from January/February to May/June.

\section{Fertilizer trials}

Three multi-year fertilizer trials with NPK were conducted at São Carlos in the state of São Paulo, Brazil, on a Red-Yellow Oxisol, epieutrophic, endodystrophic, of moderate, medium texture, cerrado phase and relief plan. A series of N-P-K fertilizer experiments were started in April/May 1989 with one-year old 'Paluma' seedlings propagated from cuttings and conducted for three consecutive years. Plots consisted of four fertilized trees of which the first was the guard tree each covering $7 \mathrm{~m} \times 5 \mathrm{~m}$. Three areas received varying rates of $\mathrm{N}_{2} \mathrm{P}_{2} \mathrm{O}_{5}$ and $\mathrm{K}_{2} \mathrm{O}$ fertilizers that were arranged in randomized blocks with seven treatments and four replications. Fertilizer rates were varied to account for nutrient removal by harvest and to alter the nutrient balance.

The $1^{\text {st }}$ year, $\mathrm{N}$ treatments were $0,30,60$, $120,180,240$ and $300 \mathrm{~g}^{\text {tree }}{ }^{-1}$ of $\mathrm{N}$, supplemented with $120 \mathrm{~g}_{\text {tree }}{ }^{-1}$ of $\mathrm{P}_{2} \mathrm{O}_{5}$ and $120 \mathrm{~g}$ tree $\mathrm{e}^{-1}$ of $\mathrm{K}_{2} \mathrm{O}$. The $2^{\text {nd }}$ year, $N$ treatments were $0,60,120,240,360,480$ and $600 \mathrm{~g}_{\text {tree }}{ }^{-1}$ of $\mathrm{N}$, supplemented with $240 \mathrm{~g}$ tree ${ }^{-1}$ of $\mathrm{P}_{2} \mathrm{O}_{5}$ and $240 \mathrm{~g}^{\text {tree }}{ }^{-1}$ of $\mathrm{K}_{2} \mathrm{O}$. The $3^{\text {rd }}$ year , $\mathrm{N}$ treatments were $0,90,180,360,540,720$ and $900 \mathrm{~g}$ tree ${ }^{-1}$ of N, supplemented with $240 \mathrm{~g}^{\text {tree }}{ }^{-1}$ of $\mathrm{P}_{2} \mathrm{O}_{5}$ and $360 \mathrm{~g}^{\text {tree }}{ }^{-1}$ of $\mathrm{K}_{2} \mathrm{O}$.

The $1^{\text {st }}$ year, $\mathrm{P}$ treatments were $0,30,60$, $120,180,240$ and $300 \mathrm{~g}_{\text {tree }}{ }^{-1}$ of $\mathrm{P}_{2} \mathrm{O}_{5}$, supplemented with $120 \mathrm{~g}$ tree ${ }^{-1}$ of $\mathrm{N}$ and $120 \mathrm{~g}^{2} \mathrm{tree}^{-1}$ of $\mathrm{K}_{2} \mathrm{O}$. The $2^{\text {nd }}$ year, $P$ treatments were $0,60,120,240,360,480$ and $600 \mathrm{~g}_{\text {tree }}^{-1}$ of $\mathrm{P}_{2} \mathrm{O}_{5}$, supplemented with $240 \mathrm{~g}$ tree ${ }^{-1}$ of $\mathrm{N}$ and $240 \mathrm{~g}$ tree ${ }^{-1}$ of $\mathrm{K}_{2} \mathrm{O}$. The $3^{\text {rd }}$ year, $\mathrm{P}$ treatments were $0,60,120,240,360,480$ and 600 $\mathrm{g}$ tree ${ }^{-1}$ of $\mathrm{P}_{2} \mathrm{O}_{5}$, supplemented with $360 \mathrm{~g}^{\text {tree }}{ }^{-1}$ of $\mathrm{N}$ and $360 \mathrm{~g}^{-1} \mathrm{tree}^{-1}$ of $\mathrm{K}_{2} \mathrm{O}$.

The $1^{\text {st }}$ year, K treatments were $0,30,60$, $120,180,240$ and $300 \mathrm{~g}^{\text {tree }}{ }^{-1}$ of $\mathrm{K}_{2} \mathrm{O}$, supplemented with $120 \mathrm{~g}_{\text {tree }}{ }^{-1}$ of $\mathrm{N}$ and $120 \mathrm{~g}_{\text {tree }}{ }^{-1}$ of $\mathrm{P}_{2} \mathrm{O}_{5}$. The $2^{\text {nd }}$ year, $K$ treatments were $0,60,120,240,360,480$ and $600 \mathrm{~g}^{\text {tree }}{ }^{-1}$ of $\mathrm{K}_{2} \mathrm{O}$, supplemented with $240 \mathrm{~g}$ tree ${ }^{-1}$ of $\mathrm{N}$ and $240 \mathrm{~g}^{\text {tree }}{ }^{-1}$ of $\mathrm{P}_{2} \mathrm{O}_{5}$. The $3^{\text {rd }}$ year, $\mathrm{K}$ treatments were $0,90,180,360,540,720$ and 900 $\mathrm{g}$ tree ${ }^{-1}$ of $\mathrm{K}_{2} \mathrm{O}$, supplemented with $360 \mathrm{~g}^{\text {tree }}{ }^{-1}$ of $\mathrm{N}$ and $240 \mathrm{~g}^{2}$ tree ${ }^{-1}$ of $\mathrm{P}_{2} \mathrm{O}_{5}$.

In $\mathrm{N}$ trials, the sources of $\mathrm{N}, \mathrm{P}$ and $\mathrm{K}$ used were ammonium nitrate $(34 \% \mathrm{~N})$, simple superphosphate $\left(18 \% \mathrm{P}_{2} \mathrm{O}_{5}\right)$ and potassium chloride $\left(60 \% \mathrm{~K}_{2} \mathrm{O}\right)$, respectively. In $\mathrm{P}$ and $\mathrm{K}$ trials, the sources of $\mathrm{N}, \mathrm{P}$ and $\mathrm{K}$ used were ammonium sulfate $(20 \% \mathrm{~N})$, triple superphosphate $\left(44 \% \mathrm{P}_{2} \mathrm{O}_{5}\right)$ and potassium chloride $\left(60 \% \mathrm{~K}_{2} \mathrm{O}\right)$, respectively. The fertilizers were broadcast around the plant in a band $40 \mathrm{~cm}$ wide beyond crown projection.

\section{Soil and tissue sampling and analysis}

Soils were sampled at four locations per tree in the $0-20 \mathrm{~cm}$ at the onset of the experiments and composited per plot. Soil samples were air dried and analyzed for $\mathrm{pH} \mathrm{CaCl}$, organic matter content, $\mathrm{K}, \mathrm{Ca}, \mathrm{Mg}$ and (H+Al) (RAIJ et al., 1987). Soil analyses are presented in Table 1 . Thirty pairs of mature leaf blades and petioles ( $3^{\text {rd }}$ from shoot tip) were collected at full bloom $1.5 \mathrm{~m}$ aboveground, as described by Natale et al. (1996). Tissue samples were oven-dried at $65^{\circ} \mathrm{C}$ and analyzed for $\mathrm{N}, \mathrm{P}, \mathrm{K}$, $\mathrm{Ca}$ and $\mathrm{Mg}$ according to Bataglia et al. (1983). The $\mathrm{N}$ was determined by microKjeldahl. The $\mathrm{P}$ was quantified by colorimetry and cations by atomic absorption spectrophotometry, after nitric-perchloric digestion.

\section{Nutrient balances}

The compositional vector of tissue analyses was made of $\mathrm{N}, \mathrm{P}, \mathrm{K}, \mathrm{Ca}$ and $\mathrm{Mg}$. The SBP can be arranged in order to facilitate interpreting the balances in relation with the objectives of the study. Parent (2011) initiated the sequential binary partition (SBP) between groups of nutrients by contrasting anions $(\mathrm{N}, \mathrm{P})$ with cations $(\mathrm{K}, \mathrm{Ca}, \mathrm{Mg})$ in a physiological perspective. In the present study, we initiated the balances with a contrast between lime nutrients $(\mathrm{Ca}, \mathrm{Mg})$ and fertilizer nutrients $(\mathrm{N}$, $\mathrm{P}, \mathrm{K})$ in order to set apart the effects of liming and fertilization on leaf nutrient balance (Table 2). 


\section{Isometric log ratio transformation}

Each ilr coordinate was computed as follows (EGOZCUE; PAWLOWSKY-GLAHN, 2005):

$i l r_{j}=\sqrt{\frac{r s}{r+s}} \ln \frac{g\left(c_{+}\right)}{g\left(c_{-}\right)}$with $j=[1,2, \ldots, D \quad 1]$ eq. 1

Where $i l r_{\mathrm{j}}$ is the $j^{\text {th }}$ isometric $\log$ ratio, $r$ and $s$ represent number of components in plus $(+)$ and minus (-) groups, respectively, $g(\mathrm{c}+)$ is geometric mean of components in the plus group $c_{+}$and $\mathrm{g}\left(c_{-}\right)$ is geometric mean of components in the minus group $c$. Coefficient $\sqrt{\frac{\mathrm{rs}}{\mathrm{r}+\mathrm{s}}}$ is the balance between the number of components in the plus and minus groups.

\section{Statistical analysis}

Variance analyses were conducted using PROC MIXED in SAS vs. 9.2. The ilr computations and discriminant analyses were conducted in the $\mathrm{R}$ statistical computing environment and the compositions package (BOOGART; TOLOSANADELGADO, 2008). Critical balance ranges were derived from nutrient concentration standards of Natale et al. (2002a) and Maia et al. (2007). Briefly, concentration lower limits were rationed using the smallest values at numerator and the highest ones at denominator. Upper limits were obtained by rationing the highest concentration values at numerator and the smallest ones at denominator. Natale et al. (2002b) proposed concentration ranges of $20-23 \mathrm{~g} \mathrm{~kg}^{-1}$ of N, 1.4-1.8 $\mathrm{g} \mathrm{kg}^{-1}$ of P, $14-17 \mathrm{~g}$ $\mathrm{kg}^{-1}$ of $\mathrm{K}, 7-11 \mathrm{~g} \mathrm{~kg}^{-1}$ of $\mathrm{Ca}$, and 3.4-4.0 $\mathrm{g} \mathrm{kg}^{-1}$ of $\mathrm{Mg}$ at full bloom. Maia et al. (2007) suggested concentration ranges of $20.2-25.3 \mathrm{~g} \mathrm{~kg}^{-1}$ of $\mathrm{N}, 1.4-$ $1.5 \mathrm{~g} \mathrm{~kg}^{-1}$ of P, $19.0-21.7 \mathrm{~g} \mathrm{~kg}^{-1}$ of $\mathrm{K}, 7.7-8.3 \mathrm{~g} \mathrm{~kg}^{-1}$ of $\mathrm{Ca}$, and 2.7-2.8 $\mathrm{g} \mathrm{kg}^{-1}$ of $\mathrm{Mg}$ in leaves between bud break and fruit set.

\section{RESULTS AND DISCUSSION}

\section{Yield response to lime and fertilizers}

Guava yield increased rapidly during the first three years of establishment, reached maximum production thereafter, then declined probably due to alternate bearing (ISAGI et al., 1997). Yield potential was higher in the fertilizer than in the lime experiment (Figure 1). Guava responded significantly to liming in all years but 2006 with significant linear trend in 2002-2004-2005 and quadratic trend in 2003; and to added $\mathrm{N}$ and $\mathrm{K}_{2} \mathrm{O}$ in the $3^{\text {rd }}$ year only (linear trend). The guava crop generally shows little response to added $\mathrm{P}_{2} \mathrm{O}_{5}$ under Brazilian conditions (NATALE et al., 2002b). The linear yield increase with added $\mathrm{N}$, although modest up to $240 \mathrm{~g}$ tree $^{-1}$ of $\mathrm{N}$, was probably indicative of a competition between soil microbes and the plant for available $\mathrm{N}$ as related to rapid soil organic matter turnover rate under tropical conditions (KRULL, 2002) and the associated decrease in $\mathrm{C} / \mathrm{N}$ ratio (ZHANG; HE, 2004). The trials provided a large spectrum of fruit yields and tissue nutrient balances over the years.

\section{Critical balance ranges}

Nutrient balance ranges obtained by combining nutrient concentration standards of Natale et al. (2002b) and Maia et al. (2007) are presented in Table 3 . The balance ranges computed from Maia et al. (2007) were outside the range of balances of our topmost yielding trees (Figure 2). In particular, the $[\mathrm{N}, \mathrm{P}, \mathrm{K} \mid \mathrm{Ca}, \mathrm{Mg}],[\mathrm{N} \mid \mathrm{P}]$ and $[\mathrm{Ca} \mid \mathrm{Mg}]$ balances were too high as driven by lower $\mathrm{Ca}, \mathrm{Mg}$ and $\mathrm{P}$ and higher K leaf concentrations. Standards derived from Natale et al. (2002b) appeared to be adequate for the $[\mathrm{N}, \mathrm{P}, \mathrm{K} \mid \mathrm{Ca}, \mathrm{Mg}]$ and $[\mathrm{N}, \mathrm{P} \mid \mathrm{K}]$ balances but could be adjusted for the $[\mathrm{N} \mid \mathrm{P}]$ and $[\mathrm{Ca} \mid \mathrm{Mg}]$ balances, as suggested in Table 3.

Seasonal variations in nutrient balances are presented in Figures 3-6. The $\mathrm{N}$ balances did not appear to be limitative (Figure 3) despite significant yield response to added $\mathrm{N}$ the $3^{\text {rd }}$ year at high yield level (Figure 1). The $\mathrm{P}$ was not deficient either (Figure 4). The $\mathrm{K}$ began to be limitative after 3 consecutive years without $\mathrm{K}_{2} \mathrm{O}$ addition as shown by the excessively high $[\mathrm{N}, \mathrm{P} \mid \mathrm{K}]$ balance (Figure 5). The guava is generally responsive to $\mathrm{K}_{2} \mathrm{O}$ additions (NATALE et al., 1996) because the crop extracts 1,554 $\mathrm{g} \mathrm{ton}^{-1}$ (Fresh Fruit) of K (NATALE et al., 2002b). In comparison, other guava cultivars were reported to extract 726 to $3,130 \mathrm{~g} \mathrm{ton}^{-1}$ (Fresh Fruit) of K (HAAG et al., 1993; NATALE et al., 2002b). As a result, 80 ton ha ${ }^{-1}$ of 'Paluma' fruits extracts $124 \mathrm{~kg} \mathrm{ha}^{-1}$ of K or nearly $150 \mathrm{~kg} \mathrm{ha}^{-1}$ of $\mathrm{K}_{2} \mathrm{O}$. Since crop response and nutrient balance were satisfactory with $\mathrm{K}$ applications of 30-60 g tree $^{-1}$ of $\mathrm{K}_{2} \mathrm{O}$, the soil $\mathrm{K}$ reserves appeared to largely support crop $\mathrm{K}$ requirements at high yield level. Natale et al. (2001) showed that feldspar in the silt fraction and micas in the clay fraction contributed most to total soil $\mathrm{K}$ in a Brazilian Oxisol under guava production. The high surface charge density of kaolinite that enhances $\mathrm{K}$ dehydration also results in a high affinity of kaolinite for K (LEVY et al., 1988).

Cases of nutrient imbalance occurred during the first two years of harvest in the lime experiment (Figure 6) due presumably to limited root system as impacted by the soil acidity level. Indeed, the expansion of the root system of newly established 
guava plants is very sensitive to soil acidity (PRADO; NATALE, 2004). The [N, P, K | Ca, Mg] balance was improved the $5^{\text {th }}$ year after liming at high rate due to increasing $\mathrm{Ca}$ and $\mathrm{Mg}$ availability. The $[\mathrm{N}$, $\mathrm{P} \mid \mathrm{K}]$ and $[\mathrm{N} \mid \mathrm{P}]$ reached close to the adjusted Natale et al. (2002b) balance range the $2^{\text {nd }}$ year after liming, indicating a positive effect of liming on $\mathrm{P}$ and $\mathrm{K}$ availability. The $[\mathrm{Ca} \mid \mathrm{Mg}]$ balance was above optimum range except in year 5 when lime rate did not exceed 3.8 ton $\mathrm{ha}^{-1}$ (treatment D2). Although the lime contained both $\mathrm{Ca}$ and $\mathrm{Mg}$, the $\mathrm{Ca} / \mathrm{Mg}$ ratio was apparently too high. Although a lime rate of 3.8 ton $\mathrm{ha}^{-1}$ may suffice to reach high guava yield and proper nutrient balance, a higher lime rate may be necessary when high rates of ammonium-based fertilizers are applied. Natale et al. (2007) and Prado and Natale (2004) recommended to maintain base saturation of $\mathrm{CEC}$ close to $55 \%$ and $\mathrm{pH} \mathrm{CaCl}_{2}$ above 5.3 during at least 40 months with a minimum lime rate of 5.6 $\mathrm{t} \mathrm{ha}^{-1}$.

To conclude, guava yield and nutrient balance across a large spectrum of liming and fertilization regimes allowed defining balance ranges that appeared to differ from current nutrient norms either at lower or upper boundaries. The crop appeared most responsive to $\mathrm{K}$ and lime. Liming appeared to be of utmost importance in the mineral nutrition of guava, as shown by greater influence than fertilization on yearly variation of nutrient balances. However, the $\mathrm{Ca}$ and $\mathrm{Mg}$ balance in liming materials must be adjusted to plant requirements.

TABLE 1- Soil properties at the onset of experiments.

\begin{tabular}{|c|c|c|c|c|c|c|c|}
\hline Trials & $\mathrm{pH} \mathrm{CaCl}{ }_{2}$ & Organic matter & r Resin-P & K & $\mathrm{Ca}$ & $\mathrm{Mg}$ & $\mathrm{Al}$ \\
\hline & & $\mathrm{g} \mathrm{dm}^{-3}$ & $\mathrm{mg} \mathrm{dm}^{-3}$ & & & $1 \mathrm{dm}^{-3}$ & \\
\hline Fertilization & 5.3 & 19 & 19 & 0.5 & 14 & 8 & 18 \\
\hline Liming & 4.7 & 18 & 6 & 1.3 & 9 & 4 & 40 \\
\hline
\end{tabular}

TABLE 2- Sequential orthogonal partitions of leaf macronutrients.

\begin{tabular}{|c|c|c|c|c|c|c|c|c|}
\hline $\mathrm{Il} r$ & & & utri & ents & & Ratio & $\mathrm{r}^{1} \mathrm{~s}$ & Ilr computation \\
\hline & $\mathrm{N}$ & $\mathrm{P}$ & $\mathrm{K}$ & $\mathrm{Ca}$ & $\mathrm{Mg}$ & & & \\
\hline 1 & 1 & 1 & 1 & -1 & -1 & {$[\mathrm{~N}, \mathrm{P}, \mathrm{K} \mid \mathrm{Ca}, \mathrm{Mg}]$} & 32 & $\sqrt{\frac{3 \times 2}{3+2} \ln \left(\frac{(N \times P x K)^{1 / 3}}{(\operatorname{CaxMg})^{1 / 2}}\right)}$ \\
\hline 2 & 1 & 1 & -1 & 0 & 0 & {$[\mathrm{~N}, \mathrm{P} \mid \mathrm{K}]$} & 21 & $\sqrt{\frac{2 x 1}{2+1} \ln \left(\frac{(N x P)^{1 / 2}}{K}\right)}$ \\
\hline 3 & 1 & -1 & 0 & 0 & 0 & {$[\mathrm{~N} \mid \mathrm{P}]$} & 11 & $\sqrt{\frac{1 x 1}{1+1} \ln \left(\frac{N}{P}\right)}$ \\
\hline 4 & 0 & 0 & 0 & 1 & -1 & {$[\mathrm{Ca} \mid \mathrm{Mg}]$} & 11 & $\sqrt{\frac{1 x 1}{1+1} \ln \left(\frac{C a}{M g}\right)}$ \\
\hline
\end{tabular}

${ }^{1} r=$ number of positive signs and $s=$ number of negative signs. 
TABLE 3 - Optimum nutrient balance ranges $(\mathrm{LL}=$ lower limit and $\mathrm{UL}=$ upper limit) for Natale et al. (2002a) and Maia et al. (2007) nutrient sufficiency ranges for guava

\begin{tabular}{ccccccc}
\hline Balance & \multicolumn{6}{c}{ Nutrient balance range } \\
& Natale et al. (2002a) & Maia et al. (2007) & \multicolumn{2}{c}{ Adjusted Natale et al. (2002a) } \\
& LL & UL & LL & UL & LL & UL \\
{$[\mathrm{N}, \mathrm{P}, \mathrm{K} \mid \mathrm{Ca}, \mathrm{Mg}]$} & 0.108 & 0.658 & 0.572 & 0.789 & 0.108 & 0.658 \\
{$[\mathrm{~N}, \mathrm{P} \mid \mathrm{K}]$} & -0.953 & -0.635 & -1.148 & -0.920 & -0.953 & -0.635 \\
{$[\mathrm{~N} \mid \mathrm{P}]$} & 1.703 & 1.979 & 1.839 & 2.047 & 1.65 & 1.85 \\
{$[\mathrm{Ca} \mid \mathrm{Mg}]$} & 0.396 & 0.830 & 0.715 & 0.794 & 0.35 & 0.65 \\
\hline
\end{tabular}
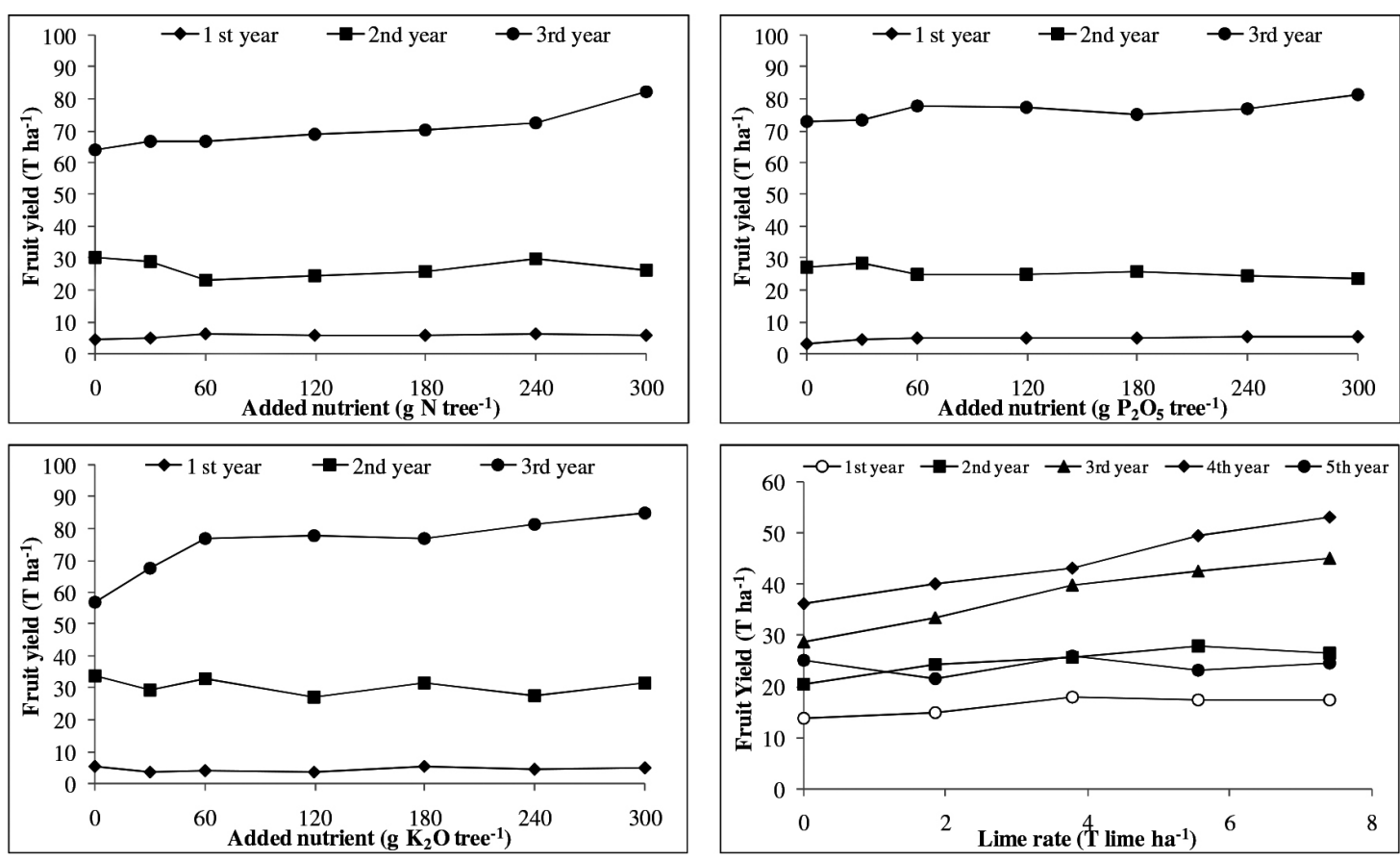

FIGURE 1- Yield response of 'Paluma' guava to N-P-K fertilization and liming.

${ }^{\dagger} \mathrm{N}$ and K Dose: $1^{\text {st }}$ year was $0,30,60,120,180,240$ and $300 \mathrm{~g} \mathrm{~N}$ and $\mathrm{K}_{2} \mathrm{O}$ tree ${ }^{-1}$, respectively, $2^{\text {nd }}$ and $3^{\text {rd }}$ year was the double and the triple of the initial doses, respectively. 

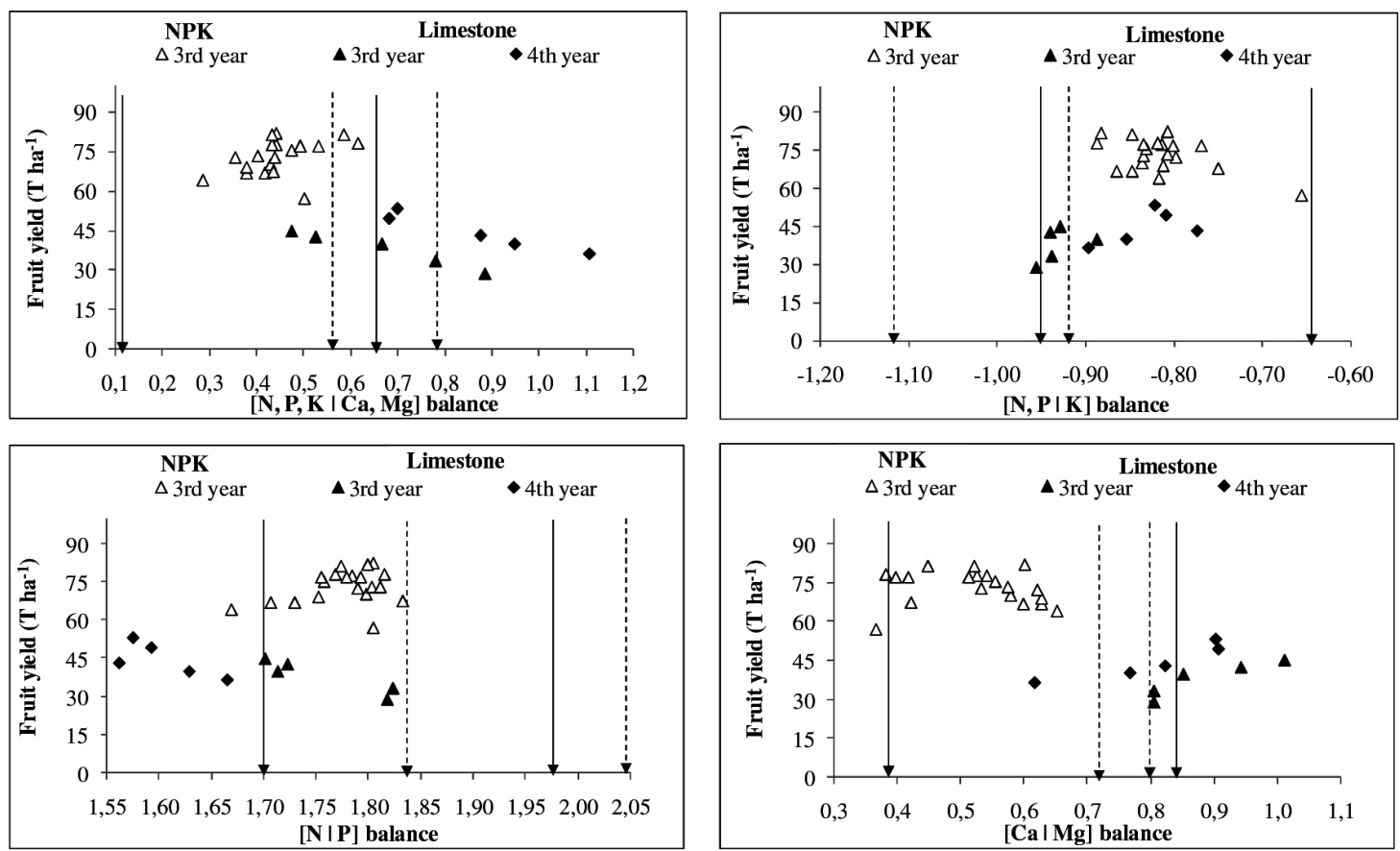

FIGURE 2- Relationship between nutrients balance and yield of 'Paluma' at full bloom. Arrows are nutrient balance ranges computed from Natale (2002b) (full arrows) and Maia et al. (2007) (dashed arrows).
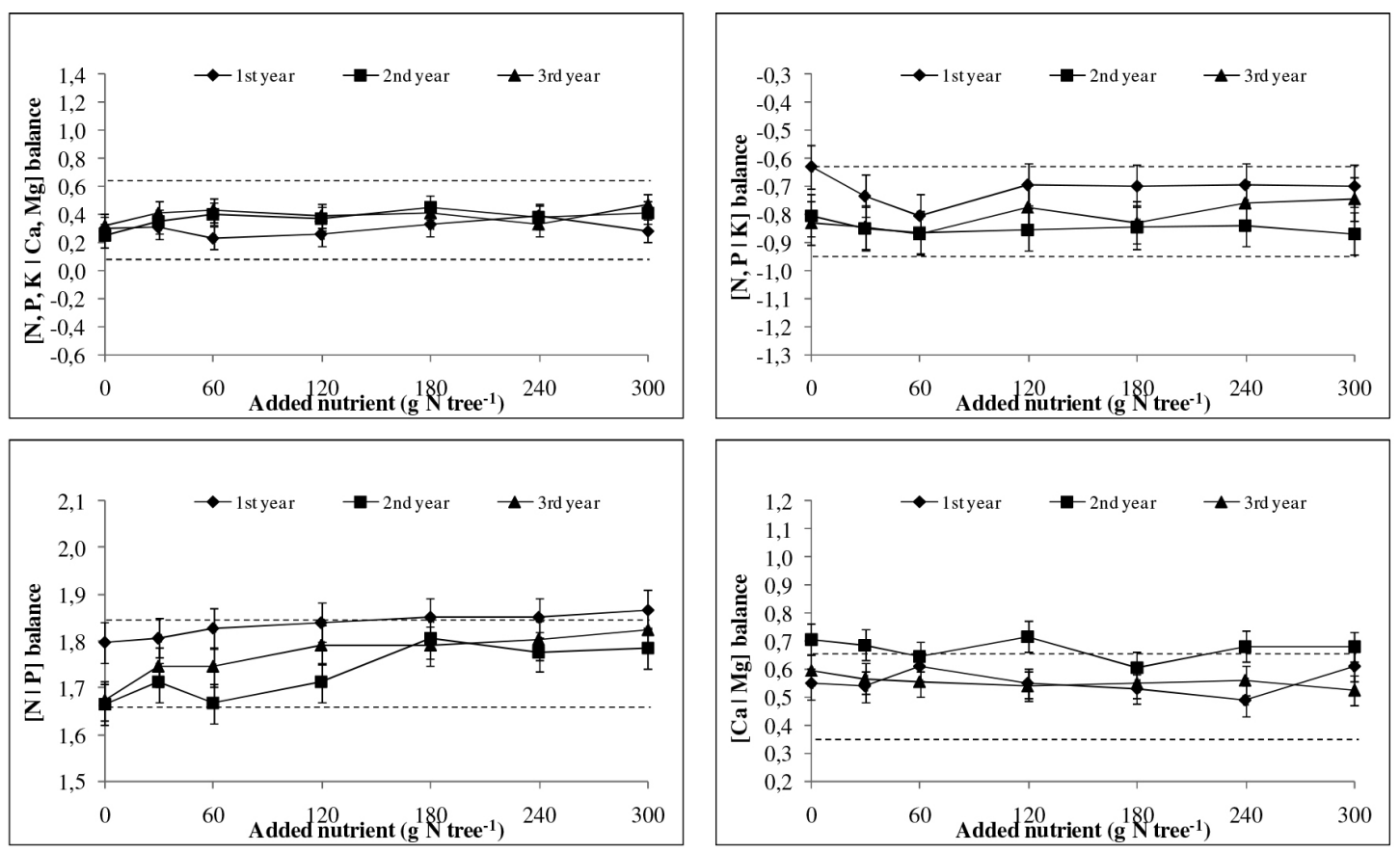

FIGURE 3 - Response of plant nutrient balances to added $\mathrm{N}$ with time (dosage doubled and tripled the $2^{\text {nd }}$ and $3^{\text {rd }}$ years, respectively). Dotted lines indicate the critical balance range. 

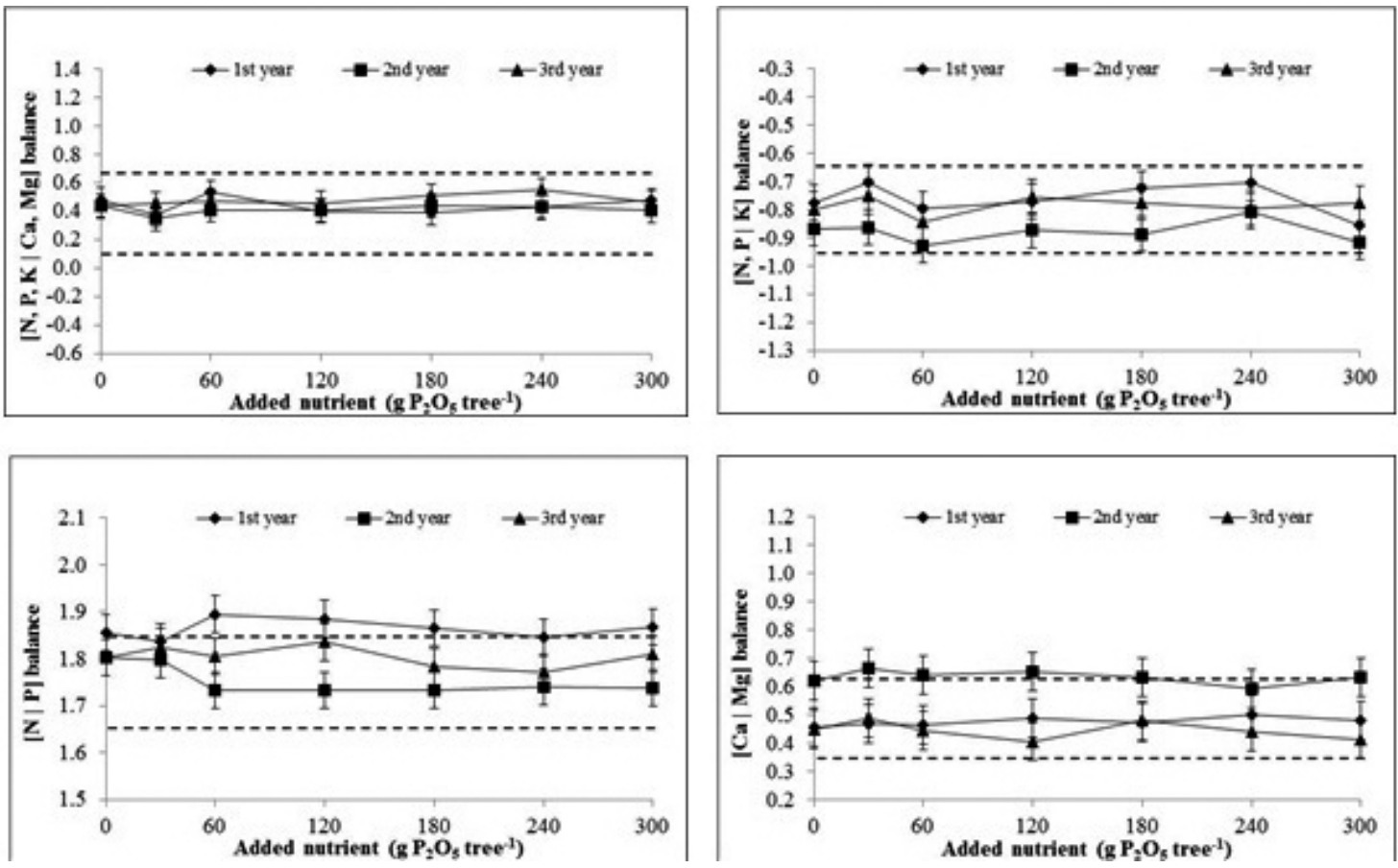

FIGURE 4- Response of plant nutrient balances to added $\mathrm{P}$ with time (dosage doubled and tripled the $2^{\text {nd }}$ and $3^{\text {rd }}$ years, respectively). Dotted lines indicate the critical balance range.
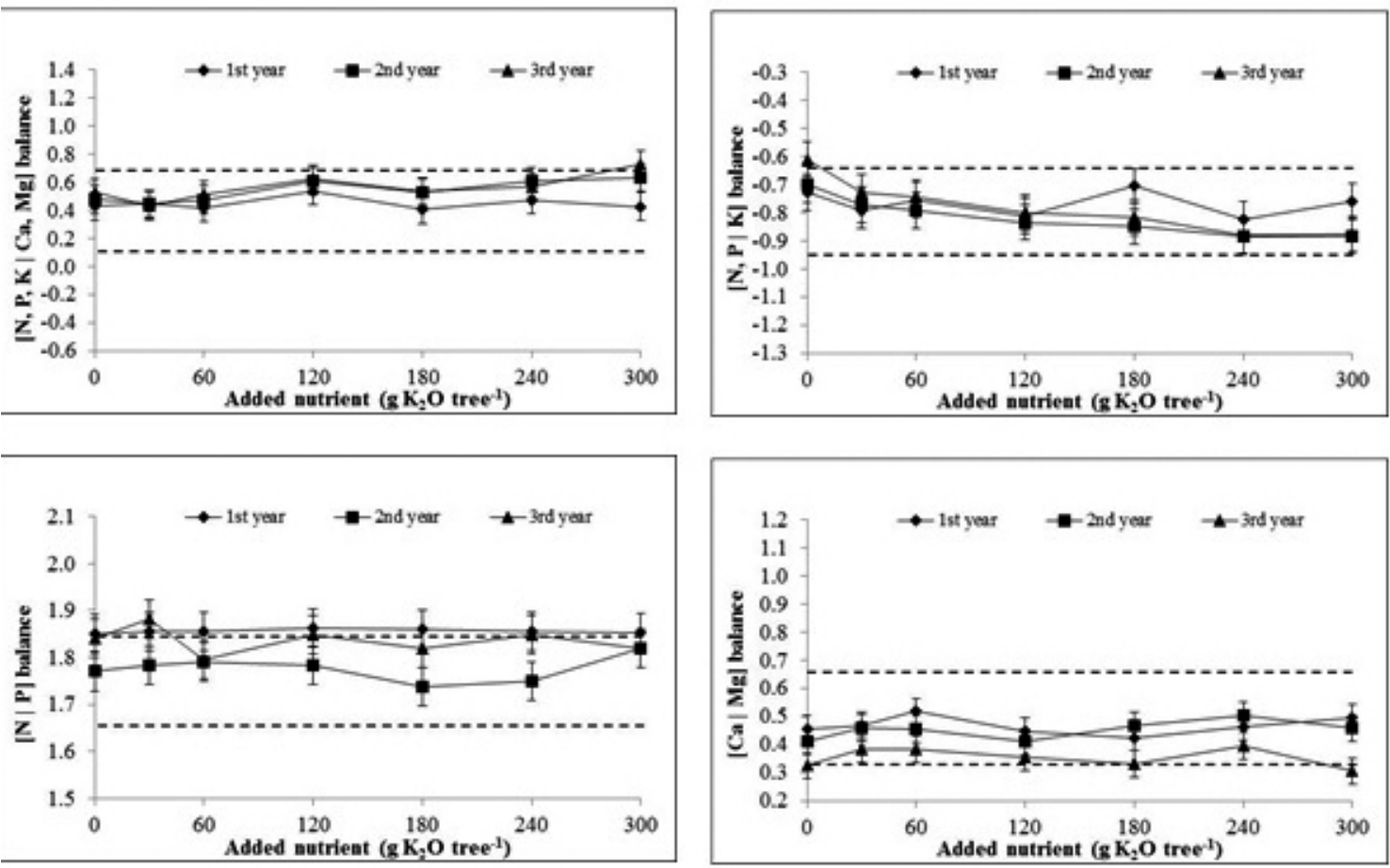

FIGURE 5- Response of plant nutrient balances to added K with time (dosage doubled and tripled the $2^{\text {nd }}$ and $3^{\text {rd }}$ years, respectively). Dotted lines indicate the critical balance range. 

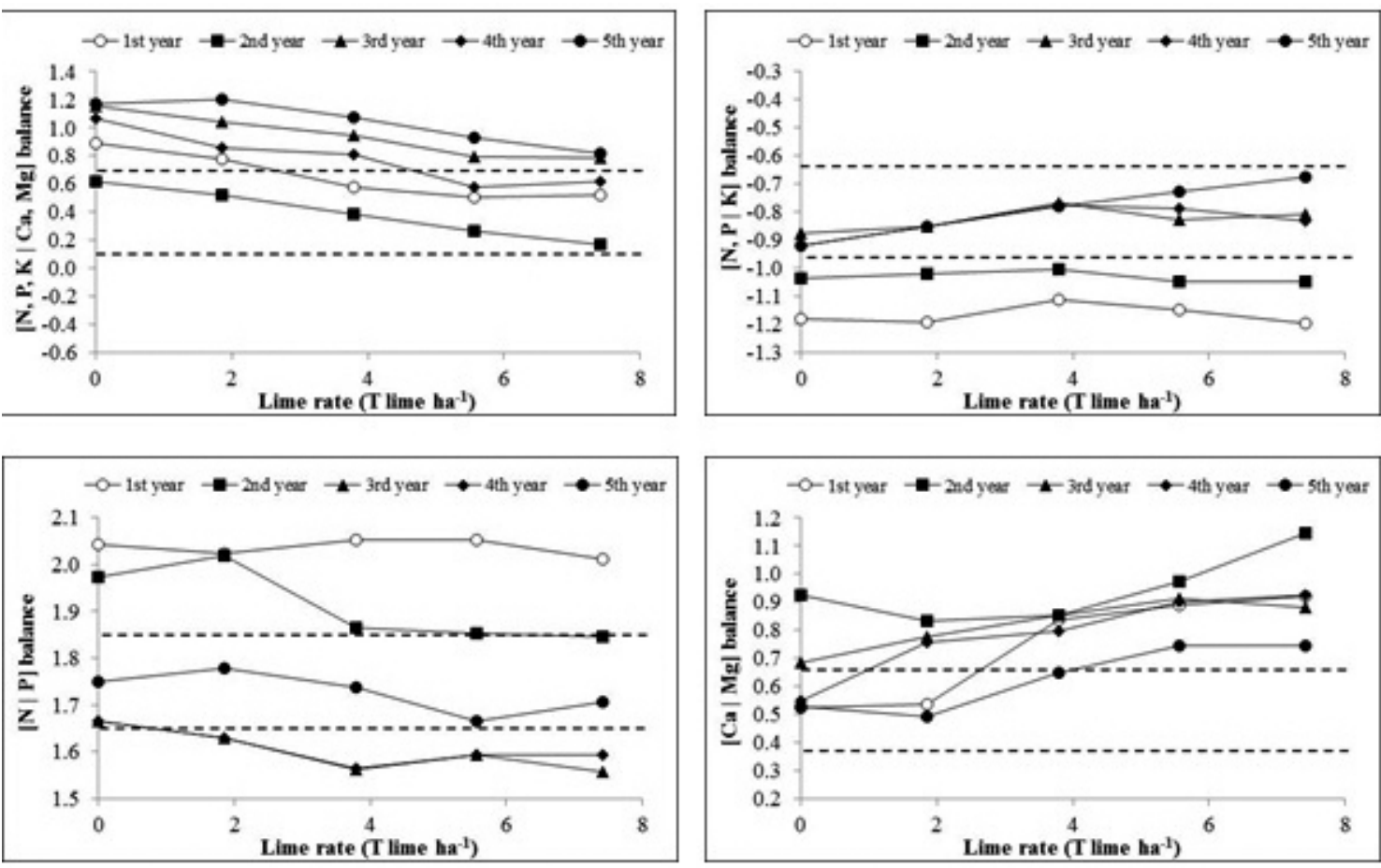

FIGURE 6 - Time change of nutrients balances at full bloom in the 'Paluma' limestone trial. Dotted lines indicate the critical balance range.

\section{REFERENCES}

AITCHISON, J. The statistical analysis of compositional data. London: Chapman \& Hall, $1986.416 \mathrm{p}$.

ANJANEYULU, K.; RAGHUPATHI, H. B. Identification of yield-limiting nutrients through DRIS leaf nutrient norms and indices in guava (Psidium guajava). Indian Journal of Agricultural Sciences, New Delhi, v. 79, p. 418-421, 2009.

BATAGLIA, O. C.; FURLANI,A. M. C.; TEIXEIRA, J. P. F.; FURLANI, P. R.; GALLO, J. R. Métodos de análise química de plantas. Campinas: Instituto Agronômico, 1983. 48 p.

BATES, T. E. Factors affecting critical nutrient concentrations in plants and their evaluation: a review. Soil Science, Baltimore, v. 112, p. 116-130, 1971.

BOOGAART, K. G. van den; TOLOSANADELGADO, R. "Compositions": a unified R package to analyze compositional data. Computers \& Geosciences, Stanford, v. 34, p. 320-338, 2008.
BOULD, C. Leaf analysis as a diagnostic method and advisory aid in crop production. Experimental Agriculture, Dundee, v. 4, p. 17-27, 1968.

EGOZCUE, J. J.; PAWLOWSKY-GLAHN, V. Análisis composicional de datos en Ciencias Geoambientales. Boletín Intituto Geológico y Minero, Madrid, v. 122, p. 439-452, 2011.

EGOZCUE, J. J.; PAWLOWSKY-GLAHN, V. Groups of parts and their balances in compositional data analysis. Mathematical Geology, New York, v. 37, p. 795-828, 2005.

EMBRAPA. Sistema Brasileiro de classificação de solos. 2. ed. Rio de Janeiro: Embrapa Solos, 2006. $306 \mathrm{p}$.

HAAG, H. P.; MONTEIRO, F. A.; WAKAKURI, P. Y. Frutos de goiaba: desenvolvimento e extração de nutrientes. Scientia Agricola, Piracicaba, v. 50, p. 413-418, 1993.

ISAGI, Y.; SUGIMURA, K.; SUMIDA, A.; ITO, H. How does masting happen and synchronize? Journal of Theoretical Biology, Amsterdam, v. 187, p. 231-239, 1997. 
KRULL, E. Soil organic matter decomposition and turnover in a tropical Ultisol: evidence from $\delta^{13} \mathrm{C}$, $\delta^{15} \mathrm{~N}$ and geochemistry. Radiocarbon, Tucson, v. 44, p. 93-112, 2002.

LAGATU, H.; MAUME, L. The variations of the sum $\mathrm{N}+\mathrm{P}_{2} \mathrm{O}_{5}+\mathrm{K}_{2} \mathrm{O}$ per 100 parts of dry material of the leaf of a cultivated plant. Comptes Rendus de l'Académie D'Agriculture de France, Paris, v. 21, p. 85-92, 1935.

LEVY, G. J.; WATT, H. V. H. van der; SHAINBERG, I.; PLESSIS, H. M. du. Potassium-calcium and sodium-calcium exchange on kaolinite and kaolinitic soils. Soil Science Society of America Journal, Madison, v. 52, p. 1.259-1.264, 1988.

MAIA, J. L. T.; BASSOI, L. H.; SILVA, D. J.; LIMA, M. A. C. D.; ASSIS, J. S. D.; MORAIS, P. L. D. D. Assessment on nutrient levels in the aerial biomass of irrigated guava in São Francisco valley, Brazil. Revista Brasileira de Fruticultura, Jaboticabal, v. 29, p. 705-709, 2007.

MALAVOLTA, E. Manual de nutrição de plantas. São Paulo: Ceres, 2006. 638 p.

NATALE, W.; COUTINHO, E. L. M.; BOARETTO, A. E.; BANZATTO, D. A. Nutrient foliar content for high productivity cultivars of guava in Brazil. Acta Horticulturae, Wageningen, v. 594, p. 383386, 2002 b.

NATALE, W.; COUTINHO, E. L. M.; BOARETTO, A. E.; BANZATTO, D. A. Phosphorus foliar fertilization in guava trees. Acta Horticulturae, Wageningen, v. 594, p. 171-177, 2002a.

NATALE, W.; COUTINHO, E. L. M.; BOARETTO, A. E.; PEREIRA, F. M. Effect of potassium fertilization in 'Rica' guava cultivation. Indian Journal of Agricultural Sciences, New Delhi, v. 66, p. 201-207, 1996.

NATALE, W.; JÚNIOR, J. M.; BOARETTO, A. E.; SIMÕES, F. L. Mineralogy and forms of potassium in Red Yellow Latosol of a guava (Psidium guajava) tree orchard. Indian Journal of Agricultural Sciences, New Delhi, v. 71, p. 166-170, 2001.
NATALE, W.; PRADO, R. M.; MÔRO, F. V. Alterações anatômicas induzidas pelo cálcio na parede celular de frutos de goiabeira. Pesquisa Agropecuária Brasileira, Brasília, v. 40, p. 1.2391.242, 2005.

NATALE, W.; PRADO, R. M.; ROZANE, D. E.; ROMUALDO, L. M. Efeitos da calagem na fertilidade do solo e na nutrição e produtividade da goiabeira. Revista Brasileira de Ciência do Solo, Viçosa, MG, v. 31, p. 1.475-1.485, 2007.

PARENT, L.E. Diagnosis of the nutrient compositional space of fruit crops. Revista Brasileira de Fruticultura, Jaboticabal, v. 33, p. 321-334, 2011.

PARENT, L.E.;ALMEIDA, C.X. de; HERNANDES, A.; EGOZCUE, J. J.; GÜLSER, C.; BOLINDER, M. A.; KÄTTERER, T.; ANDREN, O.; PARENT, S. E.; ANCTIL, F.; CENTURION, J. F.; NATALE, W. Compositional analysis for an unbiased measure of soil aggregation. Geoderma, Amsterdam, v. 179, p. 123-131, 2012.

PARENT, L. E.; DAFIR, M. A theoretical concept of compositinal nutrient diagnosis. Journal of the American Society for Horticultural Science, Mount Vernon, v. 117, p. 239-242, 1992.

PRADO, R. M.; NATALE, W. Calagem na nutrição de cálcio e no desenvolvimento do sistema radicular da goiabeira. Pesquisa Agropecuária Brasileira, Brasília, v. 39, p. 1007-1012, 2004.

PRADO, R. M.; NATALE, W. Effect of liming on the mineral nutrition and yield of growing guava trees in a typic Hapludox soil. Communications in Soil Science and Plant Analysis, Philadelphia, v. 39, p. 2191-2204, 2008.

RAIJ, B. van; QUAGGIO, J. A.; CANTARELLA, H.; FERREIRA, M. E.; LOPES, A. S.; BATAGLIA, O. C. Análise química do solo para fins de fertilidade. Campinas: Fundação Cargill, 1987. 170 p.

SANTOS, R. R.; QUAGGIO, J. A. Goiaba. In: RAIJ, B.van; CANTARELLA, H.; QUAGGIO, J. A.; FURLANI, A. M. C. (Ed.). Recomendações de adubação e calagem para o Estado de São Paulo. Campinas: Instituto Agronômico, 1996. p. 143. 
TOLOSANA-DELGADO, R.; BOOGART, K. G van den. Linear models with compositions in $\mathrm{R}$. In: PAWLOWSKY-GLAHN, V.; BUCCIANTI, A. (Ed.). Compositional data analysis: theory and applications. New York: John Wiley and Sons, 2011. p. 356-371.

WALWORTH, J. L.; SUMNER, M. E. Foliar diagnosis: a review. Advances in Plant Nutrition, New York, v. 539, p. 193-240, 1988.
ZHANG, M.; HE, Z. Long-term changes in organic carbon and nutrients of an Ultisol under rice cropping in southeast China. Geoderma, Amsterdam, v. 118, p. $167-179,2004$. 